\title{
POLLEN SEQUENCE OF THE TLALOQUA CRATER (LA MALINCHE VOLCANO, TLAXCALA, MEXICO)*
}

\author{
Dieter Ohngemach**
}

The Tlaloqua crater is situated some $25 \mathrm{~km}$ north-east of Puebla at an altitude of about $3,100 \mathrm{~m}$ on the western slope of the 4,461 $\mathrm{m}$ high Malinche volcano. It is surrounded by a light mixed forest, chiefly composed of Abies religiosa, Pinus montezumae and Alnus firmifolia. The treeless bottom of the crater has a diameter of $150-200 \mathrm{~m}$. Within the (rater we find a well, dug by the Malinche Commission. From there a trench, 1.5 to $2 \mathrm{~m}$ deep, leads northwards to the border of the crater. The upper samples for pollen analysis could be taken directly from the trench wall. Then sampling was extended below the trench bottom by a chamber sampler; two $1.3 \mathrm{~m}$ cores were taken from two sites about 30 $\mathrm{m}$ apart. The sandy-gravelly subsoil below resisted further drilling with this sampler.

The stratigraphic sequence of the profile is as follows (see Fig. 4): below about $40 \mathrm{~cm}$ of soil, well stratified pumice is encountered to a depth of $1.7 \mathrm{~m}$. The upper layers of the gyttja below that pumice are black and partly wet, the lower ones are brown, solid and more or less sandy. The occurrence of pollen of aquatic plants like Potamogeton, Hriophlllum. Limna and Utricularia proves that there are indeed organic limnic sediments; Pediastrum was preserved, too. The gyttia lies on sandy-gravelly layers.

The oldest sediments were found in the profile Tlq. II (Fig. 1). What is particularly striking in the diagram apart from the dominance of Pinus among the trees, is the extremely high percentages of nonarboreal pollen below $2.1 \mathrm{~m}$ (Here it must be mentioned that in this diagram the basic pollen sum is made up of the pollen of trees; the percentages of herbs and shrubs are calculated on this arboreal pollen basis. Therefore the NAP percentages may exceed $100 \%$ ). As can be seen, the NAP percentages in this zone mostly amount to more than $200 \%$, and even more than $300 \%$ is reached. The NAP flora is dominated by Gramineae, the rest consists mainly of Compositae, other families or genera altogether come up to $10-20 \%$ only.

The results of surface pollen analysis show how we are to interpret these high percentages of non-arboreal pollen. Values of $200 \%$ and more were found only in areas which are today devoid of forests. Surface samples, collected in various forest types vielded much lower NAP percentages $(5.40 \%$ ). But that means that the surroundings of the crater were non-forested when these sediments rich in NAP were deposited.

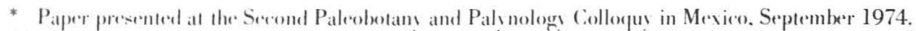

** Dr. Dieter Ohngemarh. Betanisches Institut der Unirersital Kiel. D.23 K iel. Dusternbrooker Werg 17. BRI).

Ohngemach D. 1977. Pollen sequence of the Tlaloqua crater (La Malinche volcano, Tlaxcala, Mexico). Boletín de la Sociedad Botánica de México 36: 33-44. 
Reforestation then must have happened rapidly because within only $10 \mathrm{~cm}$ of profile (between 2.1 and $2.0 \mathrm{~m}$ ) the NAP values decrease to a tenth of the former values. An idea of how far that time dates back is given by the radiocarbon dating of a sample taken from the black gyttja which, on account of its pollen spectrum, corresponds to a depth of about $1.7 \mathrm{~m}$ and which gave a C-14 age of 7,970 \pm 70 B.P. (sample no. Ki-745). Therefore reforestation occurred more than 8,000 years ago.

It is useful to deal now with some research results of Heine (1973a-c, 1975) who thoroughly investigated the Late-Quaternary history of the Malinche volcano. Heine has pointed out that there were four glaciations on the Malinche volcano during Late Pleistocene and Holocene. One of these glaciations, called M III, ocurred between 10,000 and 9,000 (years) B. P., and the glaciar advanced twice during this time. Moraines of both advances were found by Heine in the neighbourhood of the crater. Furthermore, Lauer (1973) assumed that the upper limit of the forest (now adavs at 3,900 $\mathrm{m}$ on the Malinche) was $600-800 \mathrm{~m}$ lower at the time of the M III glaciation. Both the observation of Heine and the assumption of Lauer allow us to presume that the crater must have been situated close to the upper limit of the forest, during M III.

Supported by the C-14 date of our profile we can doubtless correlate the zone rich in NA.P with the M III glaciation or a part of it. During this time the crater was situated clearly above the upper limit of the forest as is proved by the high percentages of NAP. Obviously reforestation started at the beginning of a warmer and drier climate following the M III glaciation.

As mentioned above, the NAP flora consists principally of Gramineae and Compositae. Among the last ones Artemisia occurs consistently. The pollen of Chenopodiaceae or Amaranthaceae, Caryophyllaceae, Umbelliferae, Cyperaceae, Plantago, Geraniaceae, Thalictrum and other Ranunculaceae is found also rather regularly. Less frequent is the pollen of Labiatae, Fabaceae and Brassicaceae. The vegetation of that time obviously corresponded largely to the one which can be found todav, according to the statements of Beaman (1965) and Ern (1972a,b) in the zone between the upper limit of forest and an altitude of about $4,300 \mathrm{~m}$. Súrface samples from these elevations ought to vield pollen spectra similar to those of our fossil samples rich in NAP. This is still to be verified.

But it is quite sure that during the last period of the Pleistocene, the alpine grassland (= Zacatonal according to Miranda and Hernández X., 1963) covered and area clearly larger than nowadays. In this connection it may be mentioned that Rzedowski (1975), in view of the effects of the Pleistocene glaciations is of the opinion that "a simple temperature descent of $45^{\circ} \ldots$ would have been sufficient to extend the area of grasslands over wide surfaces of northeastern and northwestern Mexico". Such a temperature descent of 4" actually happened during the M III glaciation (Lauer 1973).

The percentages of Maydeae pollen grains (long axis $60 \mathrm{um}$ and more) are given in the diagram in a separate column. The question whether these grains originate from Tripsucum. Euchlaena or maize can be answered only partly. Most likely Tripsacum is 


\section{OHNGEMACH, POLLEN SEQUENCE OF THE TLALOQUA CRATER}

not present. This results from the average size of 79.1 um received by measurements of 100 of such Mavdeae pollen grains. (According to Barghoorn et al., 1954, the genus Tripsacum has an upper extreme of 64.0 um; Tsukada, 1964, reports an upper extreme of 70.5 um in Tripsarum lanceolatum). Moreover, all fossil Mavdeae pollen grains from the Tlaloqua crater, as far as investigated with phase-contrast light, showed a pattern typical of maize and teosinte (cp. Irwin and Barghoorn, 1965). But the problem of whether maize or teosinte or even both are represented could not be resolved by phase-contrast microscopy.

Fig. 2 shows the results of size frequency studies of Maydeae pollen grains*). We can set that the curve of the fossil Maydeae pollen grains from the Tlaloqua crater has a position between the curves of Euchlaena mexicana on the one hand and two modern races of maize (cultivated in Europe) on the other, through with a distinct tendency to teosinte. (According to Barghoorn et al., 1954, the average size of teosinte pollen varies between 79.3 and $86.4 \mathrm{um}$ with an upper extreme of $102 \mathrm{um}$; Tsukada, 1964, reports and upper extreme of Eiuchlarna mexicana pollen of 89 um. In the races of maize, investigated by Barghoorn et al. the average range fluctuated between 87.2 and 122.8 um with extremes of 72.0 and 141.7 um).

The, results of size frequency studies of fossil maize pollen grains from profiles of lake Acuitlapilco (4 km south of Tlaxcala) are given in Fig. 2, too. As these grains originate from young sediments (at a maximum perhaps 1,000 years old) from a region occupied by men for a long time, we can surely sav that these fossil grains are indeed pollen grains of cultivated maize. We can see that its curve of size distribution lies below that of modern maize but above that one of the fossil Mavdeae pollen grains from the Tlaloqua crater.

These size frequency studies do not allow a definite conclusion. Indeed, it is more probable that the fossil Mavdeae pollen grains from the Tlaloqua crater originate from Eiuchluena. but we cannot completely exclude a possible participation also of maize. In that case it must be pollen of wild maize, because it has been accepted unil now that the cultivation of maize began at about 3,500 B. C., but these fossil Maydeae pollen grains are more than 8,000 vears old. Here it may be mentioned that four very old fossil pollen grains of wild maize were found by Bartlett et al. (1969) in a sample of a core from the Gatun basin in Panama which is between 6,230 and 7,300 years old. Their size varied from 100 to $110 \mathrm{um}$. (The single Maydeae pollen grain from the Tlaloqua crater exceeding 100 um was 103 um in size).

The question of whether investigations by the scanning electron microscope could be of decisive help in this problem has not been aswered yet. But according to studies of the distribution and ecology of teosinte and Tripsarum (Wilkes, 1972) it seems, however,

\footnotetext{
*' Silicone oil was the mounting medium for the pellen grains of Tripsarum and Eurhlaena. Acrording to Fangri and luesen (1964) the measured sizes were multiplied by a comersion factor of 1.25 . Perhaps. the ralues thus obtained are somewhat lese high eompared with the sizes of the other Mavdeare pollen grains mounted in pure glecrol.
} 
quite sure that the Maydeae, with its well dispersed pollen did not grow in the immediate vicinity of the crater, but that the pollen was carried upwards by wind from lower elevations.

During the M III glaciation the upper zone of the forest certainly consisted of pines just as today, for pine pollen mostly amounts to more than $80 \%$ during the time rich in NAP. Alnus and Quercus play a comparatively minor part. Presumably, their pollen originated from forests at a lower level.

Of particular interest is the occurrence of Pice't, a genus encountered in México today according to Martínez (1963) only at a few relict stations. (The nearest site of Pirec chihuahuana, the total numbers of which according to Gordon, 1968, may consist of only a few hundred individuals, is situated $900 \mathrm{~km}$ north-west of the Malinche volcano; Picen mexicana, also very rare, is found some $700 \mathrm{~km}$ to the north). The pollen of Picen occurs below about $2 \mathrm{~m}$ in every sample; there it is even somewhat more frequent than Abies pollen. Above the $2 \mathrm{~m}$ level, Picea is no longer found (In each sample of the profile, 1000 arboreal pollen grains were scanned; usually 500 were counted). It is remarkable that the extinction of Picea coincides with the rapid decrease of the NAP curve. Certainly this coincidence is not accidental. According to Heine the climate was cooler and more humid that today during the two M III glacial advances. Such a climate mav have been the precondition for the former presence of spruce at the Malinche volcano, as is also evident in the studies of ecologv of Picea chihuahuana by Gordon (1968). When the climate became drier and warmer after the M III glaciation, Purea was not able to persist any longer and died out.

The extinction of Picet, together with the rapid decrease of the high NAP values marks a distinct incision in the diagram. As in other Pleistocene profiles from the central Mexican highlands Piréa pollen was also found (Clisby and Sears 1955, González. Quintero, 1971; Ohngemach 1973; 1976) but not in Holocene profiles (Sears, 1952, Hutchinson et al., 1956; Ohngemach, 1973; 1976), it seems therefore legitimate to take the level marked by the extinction of Picea as the boundary between Pleistocene and Hologene vegetation. This transition can be distinctly seen in the Tlaloqua diagram. Provided that our diagram starts shortly after the beginning of M III glaciatior, at 10,000 B.P. one reaches an age of some 8,500 years for this transition, if one takes further into account a C-14 date (ca. 8,000 B.P.) for the Alnus maximum at $1.7 \mathrm{~m}$ together with the supposition of a constant sedimentation rate. This agrees well a fixation of the Pleistocene Holocene boundary based on geological palaeontological findings at 9,000 B. P. in the Mexican highlands (Heine and Heide-Weise, 1973).

In the Pleistocene zone of our diagram besides Quercus and Alnus some other holarctic decidtous trees are met with among which Fagus and Liquidambar are of particular interest. Indeed, their pollen is found with very low values but rather regularly. The region nearest to the Malinche where these trees grow today is situated on the eastern slope of the Sierra Madre Oriental. If their pollen occurred only sporadically, 


\section{OHNGEMACH, POLLEN SEQUENCE OF THE TLALOQUA CRATER}

long-distance transport from that region would account for it. But their rather consistent occurrence allows us the assumption that these trees once could be met with in the basin of Puebla itself, perhaps along stream banks or on the lowest slopes of the Malinche. Another objection to long-distance transport from the Sierra Madre Oriental is that, at least nowadars, such a pollen transport does not oceur or is not noticeable, for no pollen of Fagus or Liquidambar could be found in the many surface samples collected in the valley of Puebla itself and in the valley of El Seco east of the Malinche. Liquidambar, today much more frequent and more widespread than Fagus. occurs for the first time in samples from the border of the highlands with values between 0.1 and $0.2 \%$. The pollen of Faguss is only found in the recent pollen rain of the immediate neighborhood of its. present occurrence, with percentages as low as in the fossil samples from the Tlaloqua crater. As both diagrams of the Tlaloqua crater show, Fagus and Liquidambar. unlike Picea, were also able to persist in the Holocene for some time; this is especially true for Liquidambar.

The lower spectra of the pollen diagram Tlq. I (Fig. 4) cover once more the Pleistocene-Holocene boundary as is proved by the decrease of the NAP values, at first still exceeding $300 \%$, and by the disappearance of Picea. After the retreat of the M III glaciation and along with the increasing warmth, the forest is reaching higher elevations again, so that already some time before 8,000 B. P. the Tlaloqua crater was surrounded by a rather dense pine forest as low percentages of nonarboreal pollen and high values of Pinus show. A comparison with the present circumstances allows us to presume that this forest was composed of Pinus hartuegii.

This presumption may be supported by the following circumstantial evidence: according to statements of Ern (1972a) Pinus hartuegii is preferably infected by the parasite Arceuthobium globosum ssp. graudicaule Engelm., which belogs to the family Loranthaceae. These findings could be confirmed by observations made by the author in the Malinche region (Sánchez, 1969, mentions that Arceuchobium globosum ssp. graudicaule is a parasite on pines). The pollen of Arceuthobium is easy to identify. We can see that in both diagrams the pollen curve of Arceuthobium reaches its highest values shortly after the decrease of the curve of nonarboreal pollen but still before the percentages of Pinus diminish (see Fig. 1 and 4).

Pollen analyses of some surface samples from the Pinus hartuegii zone of the Mi. Orizaba gave the same picture: similar values of Areeuthobium, high percentages of Pinus and very low values of nonarboreal pollen (Fig. 3). This agrees perfectly with the thesis that Arceuthobium globosum ssp. graudicaule in fact a specific parasite of Pinus hartwegii. In this case we may infer the presence of the host (Piñus hartwegii) from the ocurrence of the parasite (Arceuthobium globosum ssp. graudicaule.

Evidently the region around the crater was only a transit station to higher elevations for the Pinus hurluegra forest, for it is soon replaced by an Alnus forest. That Pinus hurluegrii has disappeared is also shown by the curve of Arceuthobium which diminishes 
to insignificant nalues (see Fig. 1 and 4). It is still unclear why Alnus increased in such a striking manner. One might think of local effects (for example of a disastrous fire by which the especially fire-resistant Alnus firmifolice could have been favoured to such a high degree) or of an increase of Alnus in the course of a normal vegetational change. The latter assumption might be strengthened by the fact that in the profiles from the maar of Jalapasquillo (some $75 \mathrm{~km}$ east of Puebla) Alus also inereases temporarily after the extinction of Pirea. therefore ols iously at about the same time as at the Tlaloqua crater (Ohngemach, 1973; 1976). It is possible that Aluus. because of the minor elevation of the maar $(2,400 \mathrm{~m})$, does not reach so high values at Jalapasquillo (only about $10 \%$ ).

While the profile Tly. II ends with the dominance of Alnus. the pollen diagram Tlq. I (Fig. 4) shows that alder plavs an important part in the region around the crater for a long time even through it diminishes temporarily because of an increase of pine and a first ascent of fir. During the period rich in Alnus. NAP continues to have low values. Whereas the gyttja has a very high content of generally excellently preserved polten, it is scarce or even absent in the pumice deposits between 1.6 and $0.8 \mathrm{~m}$, so that the percentages of this zone cannot be easily compared with the others. Therefore they are not given in the diagram. Above this zone Alnus occurs once more with considerable values before it is replaced by a remarkable increase of Abies. Fir reaches a maximum of $38 \%$; this percentage exceeds such values as found in surface samples from present A hies forests. The coincidence of Alies maximum and honarboreal pollen minimum proves that there must have been a vers dense Abies forest. Constituted almost exclusively of Gramineae, a few high NAP pereentages during the increase of thies may depend on local effeets.

When and why this optimum development of Abies forests occurred can only be assumed again. Aceording to Heine (1973a-e; 1975) there oceurred on the Malinehe volcano at around 2,000 B. P.. the M IV glactation, a clearls minor glacial adrance compared with M III (its moraines can be found above the present upper limit of forest). Heine assumes increased precipitation during this time, the temperature was probabls somewhat lower, too. Such a climate may have favoured Alies. since it likes air moisture; moreover, fir is rather cold-resistant as is proved by its present occasional advances up into the Pinus hartuegii zone (according to Ern, 1974, up to a maximum of $3.700 \mathrm{~m}$ above sea level). Thus the ecological requirements of Alries might have been most perfectly met by the M IV glaciation.

Pollen diagrams of profiles from the lake of Acuitlapilco (Ohngemath. 1973; 1976), mentioned above, prove that the maximum of the Alie's phase really dates back more than 1,000 vears. This lake is situated at an altitude of $2,250 \mathrm{~m}$ in the western foreland of the Malinche just $20 \mathrm{~km}$ from the Tlaloqua crater. In the diagrams that cover the last 1.000 vears approximately, Abies is represented usually with $1.2 \%$, that is to say with the same low values as in the recent pollen rain around the lake. However, such a marked time of 4 bies as can be seen in the diagram Tly. I must have influenced rontemporaneous pollen records from Acuitlapilco, too. 


\section{OHNGEMACH, POLLEN SEQUENCE OF THE TLALOQUA CRATER}

The end of the pollen sequence from the Tlaloqua crater is characterized by the decrease of Abies and a gradual transition to a vegetation as is encountered in this elevation nowadavs. On account of the lack of thickness of the sediment, it is impossible to point out the beginning of human influence on the forest, e.g. charcoal-burning and pasturing in the forest, which doubtless caused the present conditions. The new occurrence of Mavdeae pollen grains that represent maize cultivation in the foreland or on the lower slopes of the Malinche, should still be mentioned.

\section{BIBLIOGRAPHY}

BARGHOORN, E. S., M. K. WOLFE and K. H. CLISBY. 1954. Fossil maize from the Vallev of Mexico. Bot. Hus. Leaflets. Hurrart Unir.. 16:229-240.

BARTLETT, S. A., E. S. BARGHOORN and R. BERGER. 1969. Fossil maize from Panama. Srience. 165:389, 390.

BEAMAN, J. H. 1965. A preliminary ecological study of the alpine flora of Popocatepetl and Iztaccihuatl. Bol. Sor. Bot. Mexiro. 29:63-75.

CLISBY. K. H. and P.B. SEARS. 1955. Palvnologv in Southern North America, Part III: Microfossil profiles under Mexico City correlated with the sedimentary profiles. Geol. Sor. Amerien Bull.. 66:511-520.

ERN, H. 1972a. Vegetationsstudien im ostlichen Zentralmexiko unter besonderer Berucksichtigung der Gehirgswalder im Gebiet des Puebla-Tlaxcala-Projektes der Deutschen Forschungsgemeinschaft. Manuseript, Konstanz, 123 pp.

ERN, H. 1972b. Estudio de la regetación en la parte oriental del México Central. Comunicuriones (Puebla), 6:1-6.

ERN, H. 1974. Zur Okologie und Verbreitung der Koniferen im ostlichen Zentralmexiko. Will. Dlsch. Dendrol. ('e's. 67:164-198.

FAEGRI, K. and J. IVERSEN. 1964. Texthook of Pollen Analisis. 2nd ed.. Copenhagen, 237 pp. (3rd ed., 1975, 295 pp.)

6,ONZALEZ QUINTERO, L. 1971. Pollen Sequener of Tlaparola (Late Pleisterene. 1/exirol. IIIrd internat. Palynol. Confer.. Novosibirsk. Abstracts.

GORDON. A. G. 1968. Eicology of Piera rhihuahuana Martínez. Eirology. 19:880-896.

HAWKSWORTH, F.G. and D. WIENS, 1972. Biology and Classification of Dwarf Mistletoes (Arceuthobium). Agriculture Handbook No. 401. Forest Service: United States Department of Agriculture. Washington, D.C., 234 pp.

HEINE, K. 1973a. Variaciones más importantes del clima durante los últimos 40.000 años en México. Comuniraciones (Pucebla). 7:51-58. 
HEINE, K. 1973b. Die jungpleistozanen und holozanen Gletschervorstobe am MalincheVulkan, Mexiko. Eiszeitalter und Gegenu. 23/24:46-62.

HEINE, K. 1973c. Zur Glazialmorphologie und prakeramischen Archaologie des mexikanischen Hochlandes wahrend des Spatglazials (Wisconsin) und Holozans. Erdtiunde 27:161-180.

HEINE, K. 1975. Studien zur jungquartaren Glazialmorphologie mexikanischer Vulkane, mit einem Ausblick auf die Klimaentwicklung. Das Mexitio Projetit der Deutschen Forschungsgemeinschafi. Bd. VII. Wiesbade'n. 178 pp.

HEINE, K. and H. HEIDE-WEISE. 1973. Jungquartare Forderfolgen des Malinche Vulkans und des Popocatepetl (Sierra Nevada, Mexiko) und ihre Bedeutung fur die Glazialgeologie, Palaoklimatologie und Archaologie. Munster. Forsth. Geol. Puluont. 31/32:303-322,

HEINE, K. and D. OHNGEMACH. 1976. Die Pleistozan/Holozan-Grenze in Mexiko. Munster. Forsch. Geol. Palaont., 38139: 229-251.

HUTCHInSON, G. E., R. PATRICK and E. S. DEEVEY. i956. Sediments of lake Patzcuaro, Michoacan, Mexico. Geol. Sor. Americe Bull. 67:1491-1504.

IRWIN, H. and E. S. BARGHOORN. 1965. Identification of the pollen of maize, teosinte and Tripsarum by phase contrast microscopy. Bot. Mus. Leaflets, Harvard Unil. 21:37-57.

LAUER, W. 1973. Zusammenhange zwischen Klima und Vegetation am Ostabfall der mexikanischen Meseta. Erdtiunde 27:192-213.

MaRTineZ, M. 1963. Las Pináceres Mexicanas. México, D. F., 400 pp.

MIRANDA, F. and E. HERNANDEZ X. 1963. Los tipos de vegetación de México y su clasificación. Bol. Soc. Bot. México 28:29-179.

OHNGEMACH, D. 1973. Análisis polínico de los sedimentos del Pleistoceno Reciente y del Holoceno en la región Puebla-Tlaxcala. Commnicaciones (Puebla), 7:47-49.

OHNGEMACH, D. Noticias preliminares sobre algunos diagramas polínicos del Cuaternario Superior en la región Puebla-Tlaxcala (México). In: Das Mexiko-Projekt der Deutschen Forschungsgemeinschaft, Bd. VIII. Wiesbaden (in print).

RZEDOWSKI, J. 1975. An ecologıcal and phytogeographical analysis of the grasslands of Mexico. Taxon 24(1):67-80.

SANCHEZ S., O. 1969. La flora del valle de México. México, D. F., 519 pp.

SEARS, P. B. 1952. Palynology in Southern North America, Part I: Archeological horizons in the basins of Mexico. Geol. Soc. America Bull. 63:241-254.

TSUKADA, M. 1964. Pollen morphology and identification III: Modern and fossil tropical pollen witl emphasis on Bombacaceae. Pollen et Spores 6:393-462.

WILKES, H. G. 1972. Maize and its wild relatives. Science 177:1071-1077. 


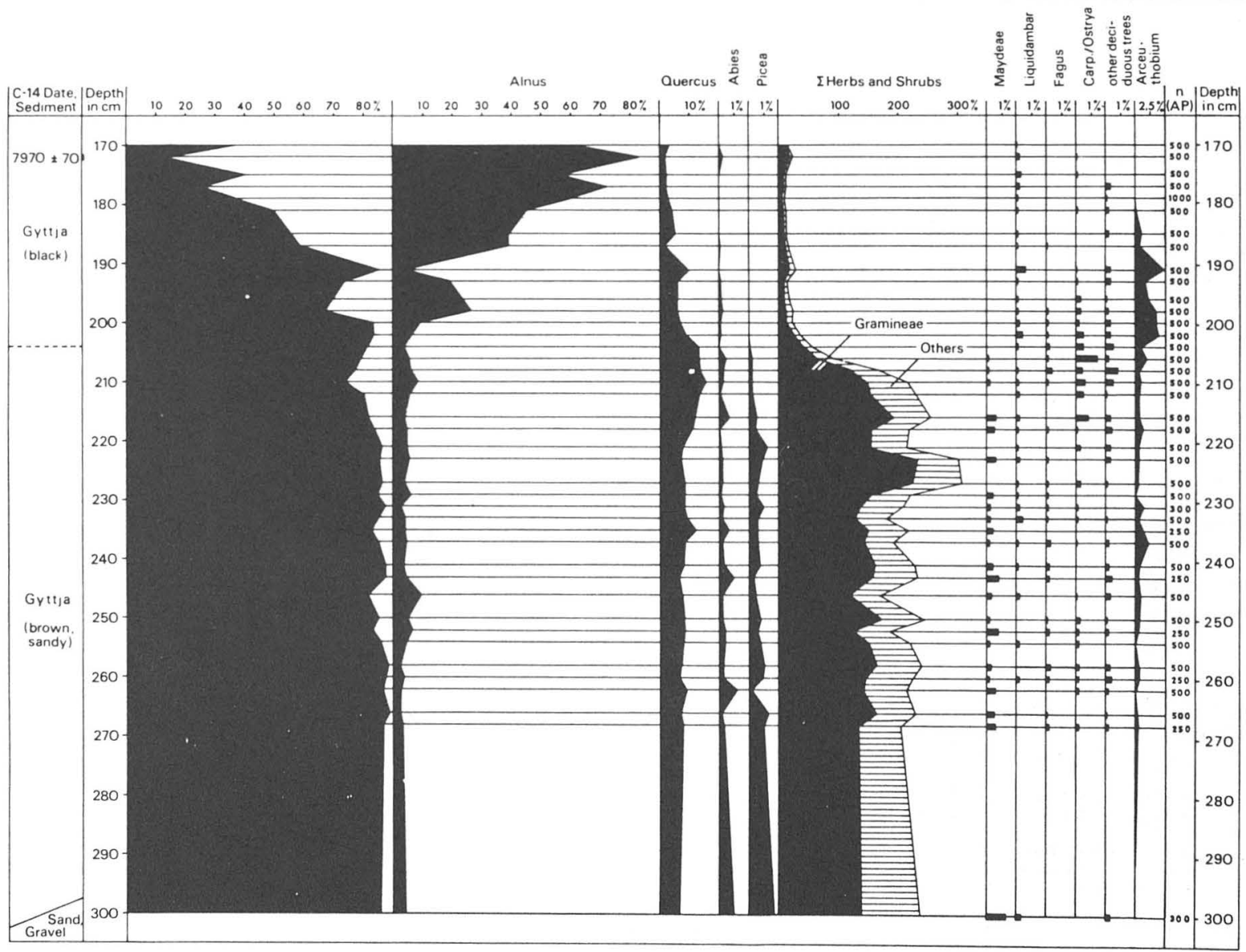

Fig. 1 Pollen diagram Tlq. II of the Tlaloqua crater $(3,100 \mathrm{~m})$. 


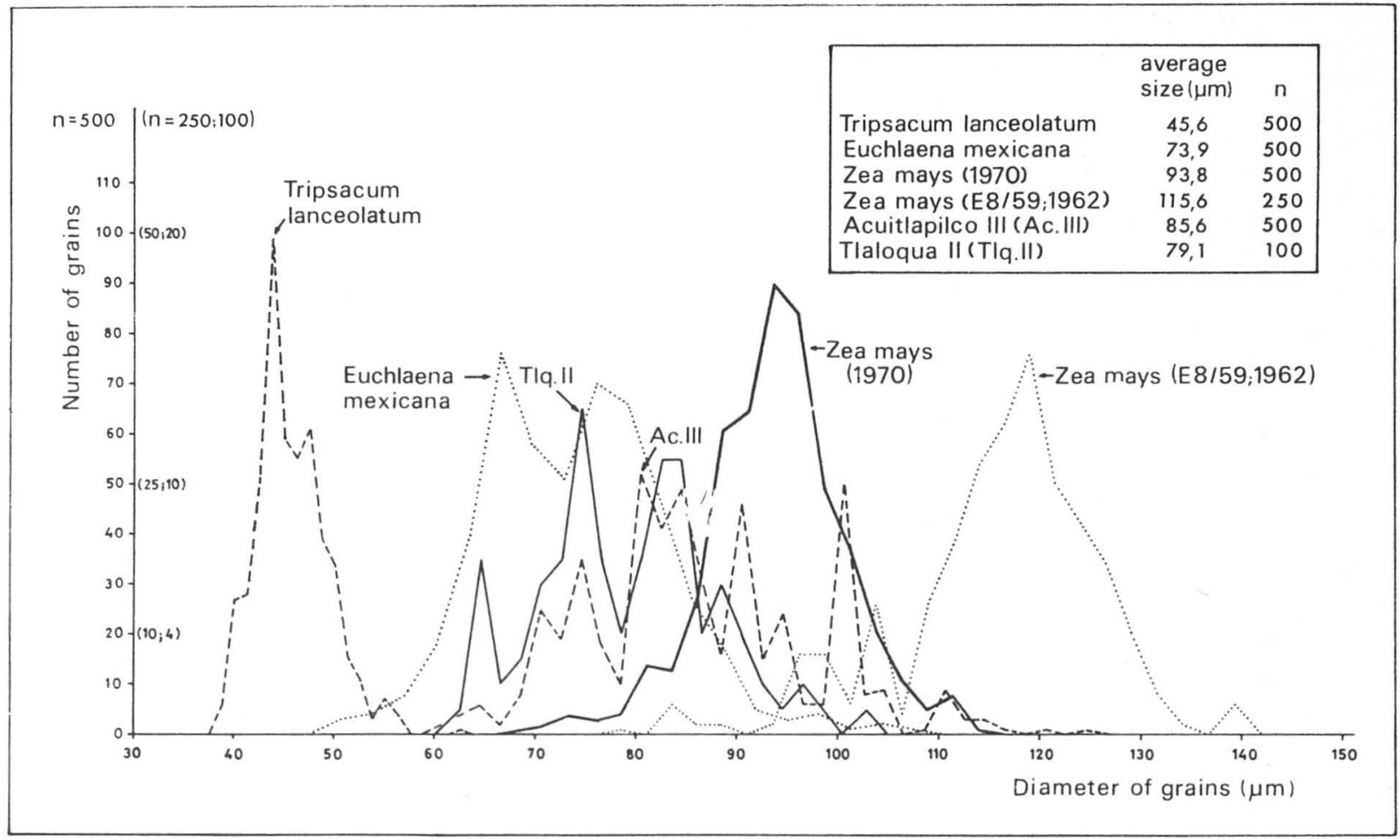

Fig. 2. Size distribution of modern and fossil Maydeae pollen grains. 


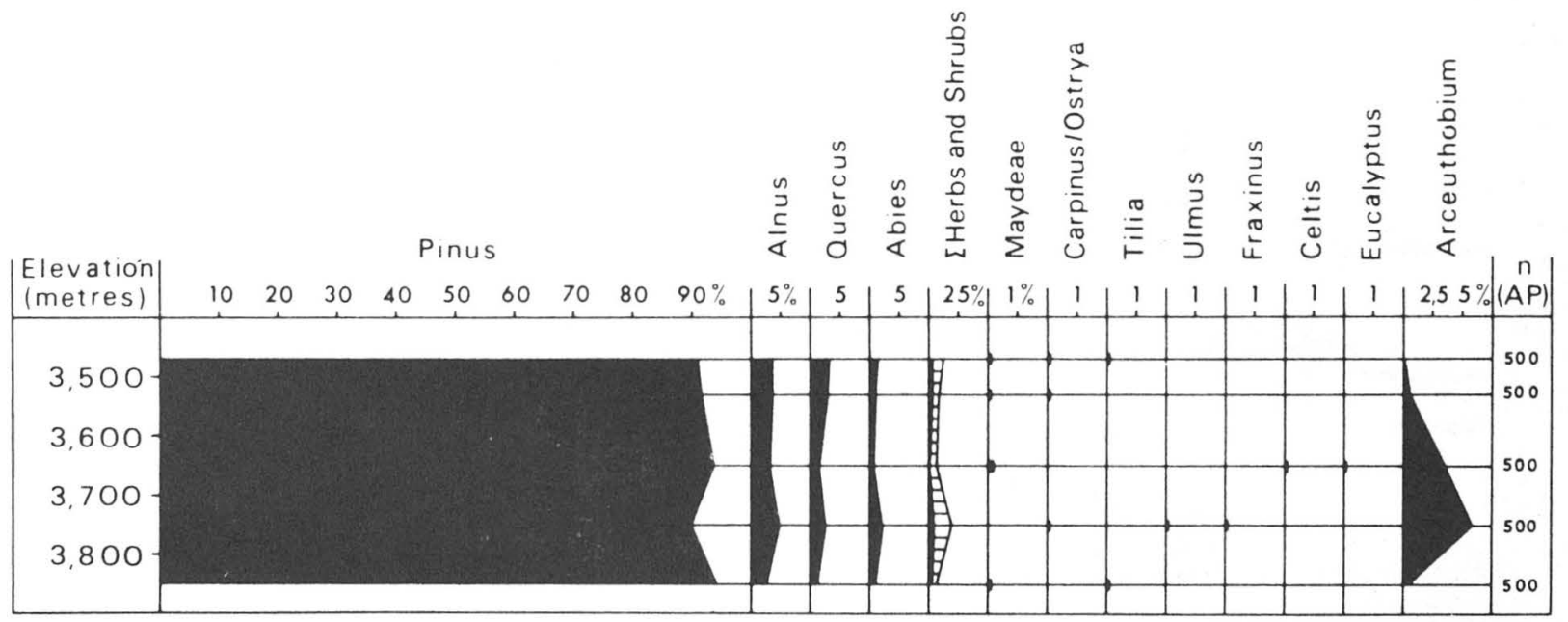

Fig. 3. Spectra of some surface samples froh the Pinus hartwegii 


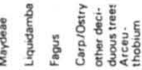

Prnus Alnus Quercus Abies o

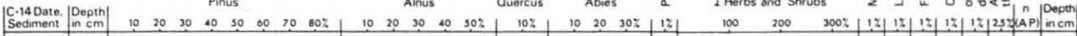

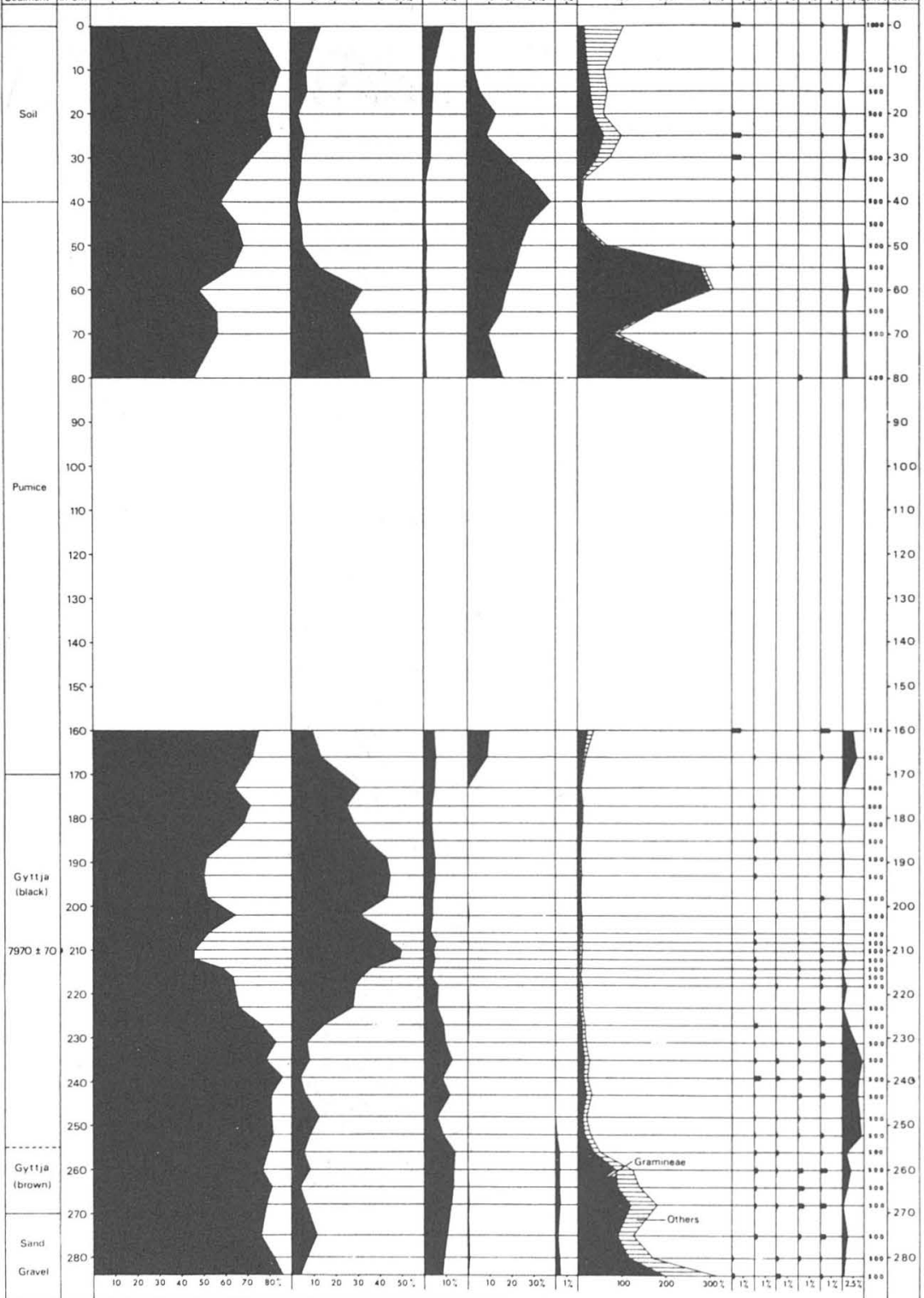

Fig. 4.-Pollen diagram Tly. I of the 'Tlaloqua crater $(3,100 \mathrm{~m})$. 